\title{
Have North Pacific killer whales switched prey species in response to depletion of the great whale populations?
}

\author{
Sally A. Mizroch*, Dale W. Rice \\ National Marine Fisheries Service, Alaska Fisheries Science Center, National Marine Mammal Laboratory, \\ 7600 Sand Point Way NE, Seattle, Washington 98115, USA
}

\begin{abstract}
Springer et al. (2003; Proc Natl Acad Sci USA 100:12223-12228) hypothesized that populations of seals, sea lions and sea otters in the northern North Pacific Ocean and Bering Sea declined because of increased predation by killer whales, in what they termed a 'sequential megafaunal collapse'. They hypothesized that the killer whales had been dependent on large whales for food, and that their increased predation on the smaller marine mammals was directly due to the depletion of great whale populations as a result of post-World War II industrial whaling. The maps presented by Springer et al. (2003) masked the development and precipitous decline of post-World War II industrial whaling. Our analysis shows that north of $50^{\circ} \mathrm{N}$, whaling developed slowly from 1948 to 1951 , expanded steadily from 1952 to 1962, and increased very sharply from 1963 to 1967 . By 1968, there was near total drop-off in catches north of $50^{\circ} \mathrm{N}$ as the whaling fleets moved south. Because of the extraordinary whale biomass removals in the mid-1960s, any whaling-related prey shifting should have started by 1968, not the mid-1970s as they suggested. We also present data that refute their assumption that North Pacific killer whales depended on large whales as prey either prior to or concurrent with the whaling era. During the years of the development and pulse of whaling (i.e. prior to 1968), less than $3 \%$ of the mammal-eating killer whales were observed to have large whale remains in their stomachs. Killer whales attack healthy, adult large whales only rarely, and such attacks are usually unsuccessful. Neither minke nor gray whales were depleted by post-World War II industrial whaling, and they have always been available as prey for North Pacific killer whales.
\end{abstract}

KEY WORDS: Whaling $\cdot$ Killer whale $\cdot$ Sequential decline $\cdot$ Sequential megafaunal collapse Resale or republication not permitted without written consent of the publisher

\section{INTRODUCTION}

Springer et al. (2003) hypothesized that post-World War II industrial whaling caused a 'sequential megafaunal collapse' - the sequential collapse of populations of seals, sea lions and sea otters in the northern North Pacific Ocean and Bering Sea because of increased predation by killer whales Orcinus orca. They asserted that mammal-eating killer whales switched to pinnipeds as prey after their preferred prey, the great whales, had been depleted by whaling. This whaling targeted 4 species of large balaenopterid whales: the blue whale Balaenoptera musculus, fin whale $B$. physalus, sei whale $B$. borealis, and humpback whale Megaptera novaeangliae and 1 large toothed whale, the sperm whale Physeter macrocephalus. We assess whether Springer et al. (2003) mis-characterized the depth and timing of the depletion of the great whales in describing post-war industrial whaling and whether their description of the development and decline of whaling in the North Pacific is accurate either temporally or geographically. Also, their assumptions about the food habits of killer whales were based mainly on conventional stereotypes and untenable extrapolations from anecdotal accounts. The scientific literature and anecdotal re- 
ports fail to provide any evidence that North Pacific killer whales were ever dependent on great whales as prey.

In this paper we present a clearer, more accurate picture of the start, development and decline of postWorld War II industrial whaling based on the dataset used by Springer et al. (2003). We also explore the historical literature and provide both quantitative and qualitative information on killer whale prey choices in the North Pacific before and during the era of postWorld War II industrial whaling.

\section{MATERIALS AND METHODS}

Catch data. We used the same dataset as Springer et al. (2003), which was collected by the Bureau of International Whaling Statistics (BIWS) and is now curated by the International Whaling Commission (IWC). Data used in our analysis are from the dataset distributed by the IWC in February 2003.

Plots of densities of whale catches (catch in numbers of whales) as carried out by Springer et al. (2003) cannot be used as a proxy for biomass removals as the whalers shifted from larger whales to smaller whales (e.g. fin whales to sei whales) after the stocks of larger whales were depleted. Because the species mix shifted, the biomass removals cannot be compared year to year. Although Springer et al. (2003) mentioned whale biomass, they did not actually show whale biomass at all in their Fig. 1 and possibly not in their Fig. 2.

Our maps present catch biomass rather than the number of whales caught and use shaded density grids that show the zones of high densities, using the 'natural breaks' algorithm (Jenks 1963) within the program ArcMap 8.2 to determine optimal class size. Dot patterns of grouped whale catches (as presented in Springer et al. 2003) cannot pictorially show the actual densities of the number of whales caught because the dots overlap.

Biomass estimates. Whale biomass was calculated using actual whale length data in the BIWS/IWC catch database. Weights were estimated for each whale caught based on length/weight curves developed for each species; see Mizroch (1983) for the method of calculation. We used the weight/length parameters calculated by Lockyer (1976) for all species except Berardius bairdii; for the latter species we used data from Balcomb (1989). Appendix 1 (available as Supplementary Material at www.int-res.com/articles/suppl/ m310p235_app.pdf) shows the length/weight parameters used for each species, as well as detailed information for each species for the entire range of the dataset, and also for those catches from $50^{\circ} \mathrm{N}$ and above.
Biomass estimates on the maps are the sums of weights for all whales caught in each $1 \times 1^{\circ}$ cell. Biomass estimates on the figures are the sums for all species combined.

Killer whale prey choice based on analysis of stomach contents. Groups of killer whales show a consistent preference for a particular kind of prey. In the northeastern Pacific, most groups of killer whales fall into one or the other of 2 categories which, for lack of a better term, may be called ecotypes (Bigg et al. 1987, Ford et al. 1998, Heise et al. 2003). These ecotypes are (1) fish-eating whales that prey on salmon, herring, and other fishes; these whales return each summer to a traditional home range in coastal waters, and (2) mammal-eating whales that prey on seals, sea-lions, porpoises, and dolphins; these animals are somewhat nomadic, with occasional incursions into the coastal habitat of the fish-eating whales. There is virtually no overlap in the diets of these 2 ecotypes.

We surveyed the literature for studies on stomach contents analyses of killer whales sampled in the North Pacific prior to 1968. Our analyses were stratified by whether the killer whale consumed fish or mammals. In the stomach contents, baleen whales are usually represented by sections of baleen and large chunks of blubber, whereas small cetaceans are represented by fragments of blubber and flesh including recognizable parts such as flukes, and pinnipeds are represented by bones, teeth, skin, hairs, vibrissae, and claws. We do not know what possible biases may be introduced by differential times of passage of these different body parts.

\section{RESULTS}

\section{Catch data}

In our analysis, we recreated Springer et al. (2003)'s Fig. 1A-D, but we selected different sets of years that better characterize the development and abrupt decline of whaling in the northern North Pacific and Bering Sea (latitude $50^{\circ} \mathrm{N}$ and above). Our Fig. 1 shows catch levels throughout the North Pacific, presenting total catch in the North Pacific, catch taken between the latitudes $30^{\circ}$ and $50^{\circ} \mathrm{N}$ and catch taken from $50^{\circ} \mathrm{N}$ and above. Catches north of $50^{\circ} \mathrm{N}$ began in 1948 and were nearly non-existent after 1975.

Post-World War II industrial whaling in the northern North Pacific had a development period (1946 to 1951, Fig. 2, similar to Springer et al. (2003)'s Fig. 1A), a period of increasing catches (1952 to 1962, Fig. 3), and then a sharp increase in 1963 with a very short era of extremely high catches (1963 to 1967, Fig. 4), a maximal catch in 1964, high catches from 1965 to 1967, then 




Fig. 1. Post-World War II industrial whaling catch levels throughout the North Pacific, including total catch in the North Pacific, catches between 30 and $50^{\circ} \mathrm{N}$ and catches from $50^{\circ} \mathrm{N}$ and above. Note that by 1968 most of the catch was taken between 30 and $50^{\circ} \mathrm{N}$

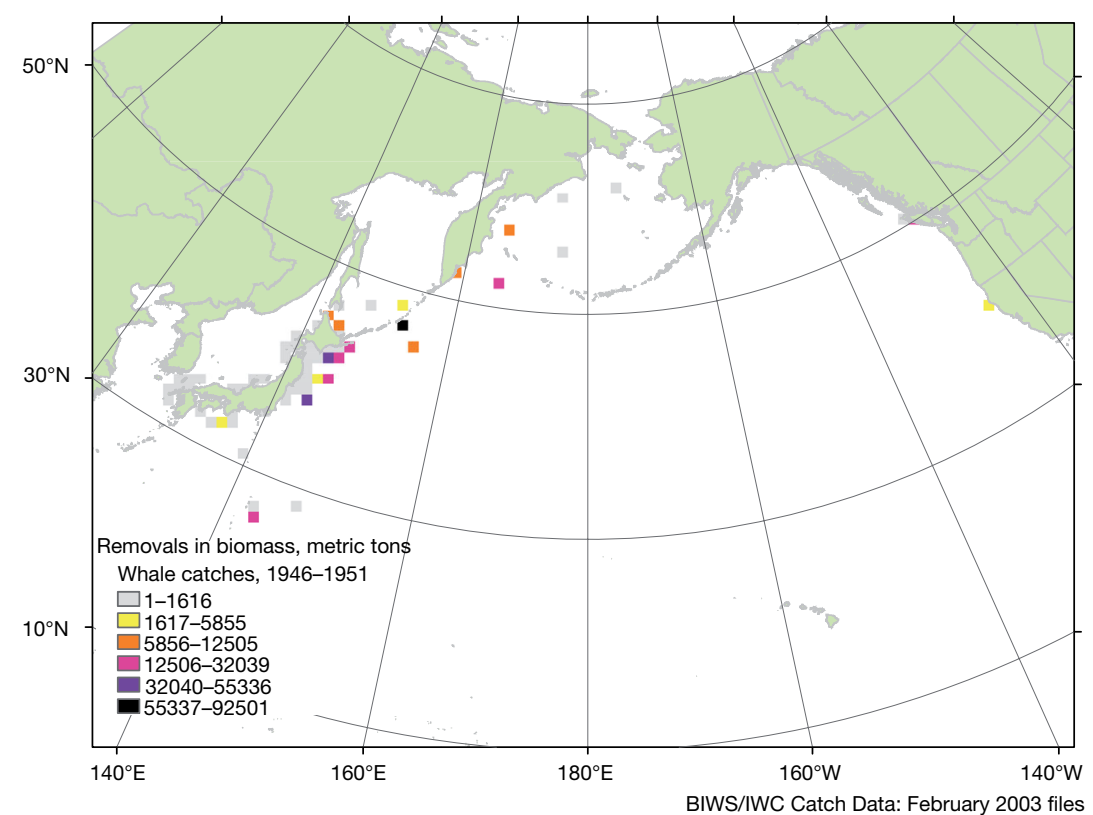

Fig. 2. Catches from 1946 to 1951, represented as biomass. These catches were taken in the first phase of whaling after World War II

a near total drop-off north of $50^{\circ} \mathrm{N}$ (Fig. 5). The IWC prohibited the killing of humpback whales in 1963 and fin whales in 1967. By 1968, most of the catch in the North Pacific was taken between 30 and $50^{\circ} \mathrm{N}$ (Fig. 1), south of the area where the pinniped declines were later discovered.

Catches taken between 1946 and 1951 were in waters near the Japanese mainland and to a small degree, off the Kamchatka peninsula (Fig. 2). Whaling did not move north of $50^{\circ} \mathrm{N}$ until 1948. During the period 1952 to 1962, catches expanded to the Aleutians, Bering Sea, and to a small degree, the Gulf of Alaska (Fig. 3). Note that catches near the Japanese mainland remained high during this period as fleet capacity expanded.

By far the largest catches in the northern North Pacific and Bering Sea $\left(50^{\circ} \mathrm{N}\right.$ and above) occurred during the period 1963 to 1967 (Fig. 4). Catches were high throughout the northern North Pacific, off Kamchatka, the Aleutians, the Bering Sea and the Gulf of Alaska, as well as near the Japanese mainland. Land stations catches at Vancouver Island and off California were also at or near maximum during this period.

From 1968 to 1972, the whaling fleets moved further south and took large catches of sperm and sei whales in the rich grounds along the Subarctic Boundary (ca. 42 N) (Fig. 5). By 1973, there was almost no whale catch north of $50^{\circ} \mathrm{N}$ (Fig. 6).

Fig. 7 shows whale catch for each species by year. Note the peak in sperm whale Physeter macrocephalus catches in 1969, and the increase in sei whale catches after 1966. Figs. $8 \& 9$ show the distribution of sperm whale catches from 1946 to 1967 and from 1968 to 1987. These show the high density of sperm whale catches in the traditional whaling areas through 1967, and the shift of sperm whale catches much farther south, starting in 1968. There were no sperm whale catches in most of the areas north of $50^{\circ} \mathrm{N}$ after 1967 . It is likely that sperm whale catches south of the area of interest caused the second big spike in Springer et al.'s (2003) Fig. 2, which would give an erroneous timeline of whale removals in the northern North Pacific.

Fig. 10 shows all years of sei whale catches; note that the primary concentration zone of sei whales has always been much farther south, in the Subarctic Boundary area (ca. $\left.42^{\circ} \mathrm{N}\right)$. So, the spike in catch levels of sei whales in 1967, as shown in Fig. 7, was predominantly caused by catches from the Subarctic Boundary.

Biomass removal totals for each species were computed using a length/weight relationship that should 




Fig. 3. Catches from 1952 to 1962, represented as biomass. This was a period of increasing catches in the post-World War II industrial whaling era as the industry expanded in equipment and range

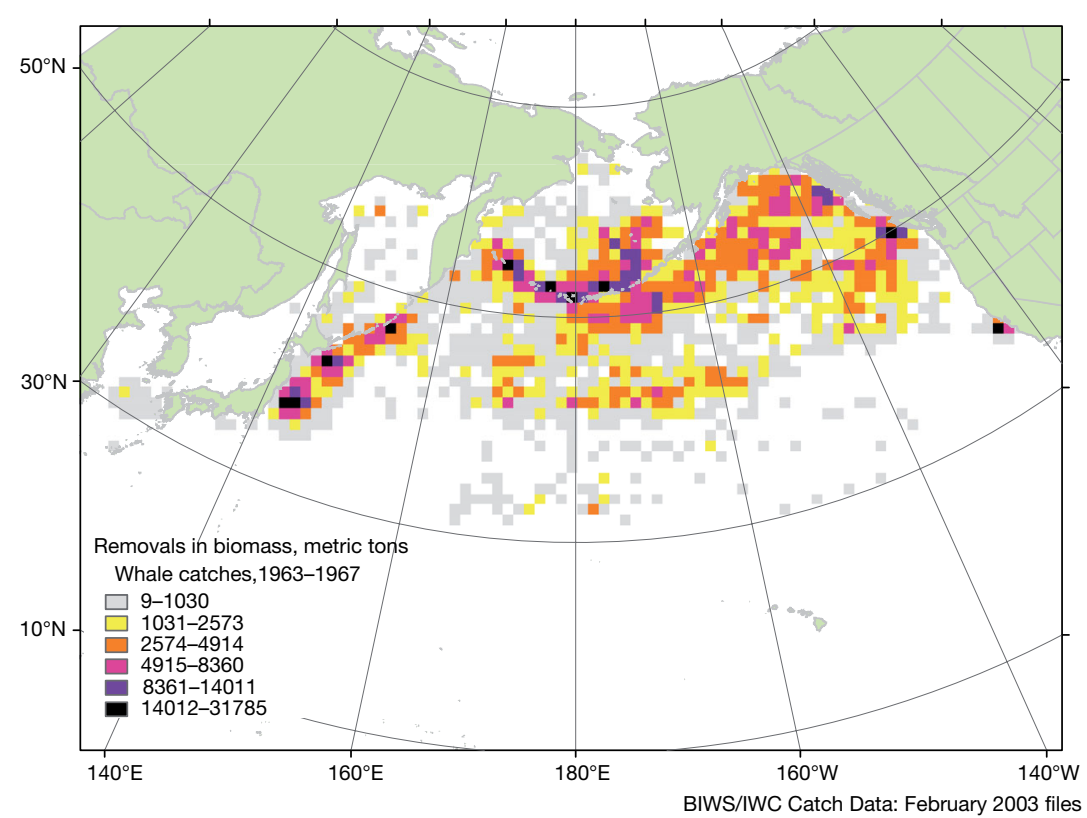

Fig. 4. Catches from 1963 to 1967, represented as biomass. This was a short era of extremely high catches. Note that there were large catches over the entire northern North Pacific, including off Kamchatka, in the Bering Sea, the Aleutian Islands and the Gulf of Alaska. Whaling station catches off Vancouver Island and off California were also very high during this period

be the best measure when looking for temporal and geographic effects of large-scale removals from an ecosystem. For catches $50^{\circ} \mathrm{N}$ and above, biomass removals were calculated for each species by year (Fig. 11), and cumulative biomass was presented for the entire range of years in the catch database
(Fig. 11). This figure confirms that the last big year of whale biomass removals north of $50^{\circ} \mathrm{N}$ was 1967 , and subsequent removals were negligible.

\section{Killer whale prey choice based on analysis of stomach contents}

Data on stomach contents are available for 442 killer whales taken in the North Pacific prior to 1968; 400 of the 442 contained food items, and 110 of these contained marine mammals, indicating that they were of the mammaleating ecotype (Table 1).

The first biologist to examine any stomachs of North Pacific killer whales was Zenkovich (1938) who examined 2 animals taken by whalers between Olyutorskiy and Anadyrskiy Gulfs in 1936. Both of the animals he sampled were mammal-eaters (mostly walrus), yet neither had large whale remains in their stomachs.

By far the largest sample was the 409 killer whales taken by whalers in the coastal waters around Japan between 1948 and 1957 (Nishiwaki \& Handa 1958). Of the 380 stomachs that had food items remaining in their stomachs, $102(26.8 \%)$ contained marine mammal parts. Of those 102, only 2 contained large whale remains (sei whales).

Ivanova (1961) examined the stomachs of 21 killer whales, also taken by whalers throughout the Kuril Islands from 1951 to 1955. Based on stomach contents, it seemed that all of the whales Ivanova sampled were fish-eaters.

Rice (1968) examined the stomach contents of 10 killer whales that were harpooned opportunistically during a number of cruises along the west coast, from Kodiak Island, Alaska south to San Miguel Island, California, from 1960 to 1967. Of the 8 stomachs that contained food items, $6(75 \%)$ contained marine mammal parts; of those, 1 contained large whale remains (minke whale Balaenoptera acutorostrata).

In summary, during the years of the development and pulse of whaling (i.e. prior to 1968), less than $3 \%$ of the mammal-eating killer whales were found to have large whale remains in their stomachs (Table 1). 


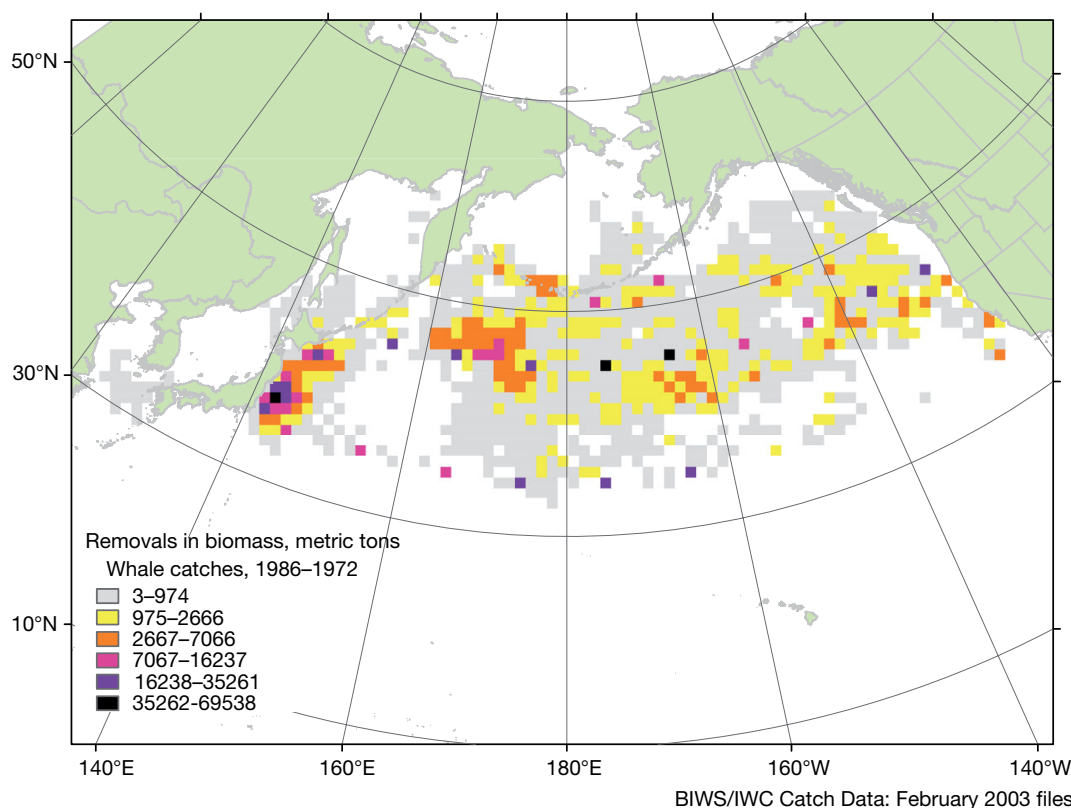

Fig. 5. Whale catches from 1968 to 1972, represented as biomass. Whalers moved south of the traditional whaling grounds and switched to the rich grounds along the Subarctic Boundary area (ca. $42^{\circ} \mathrm{N}$ )

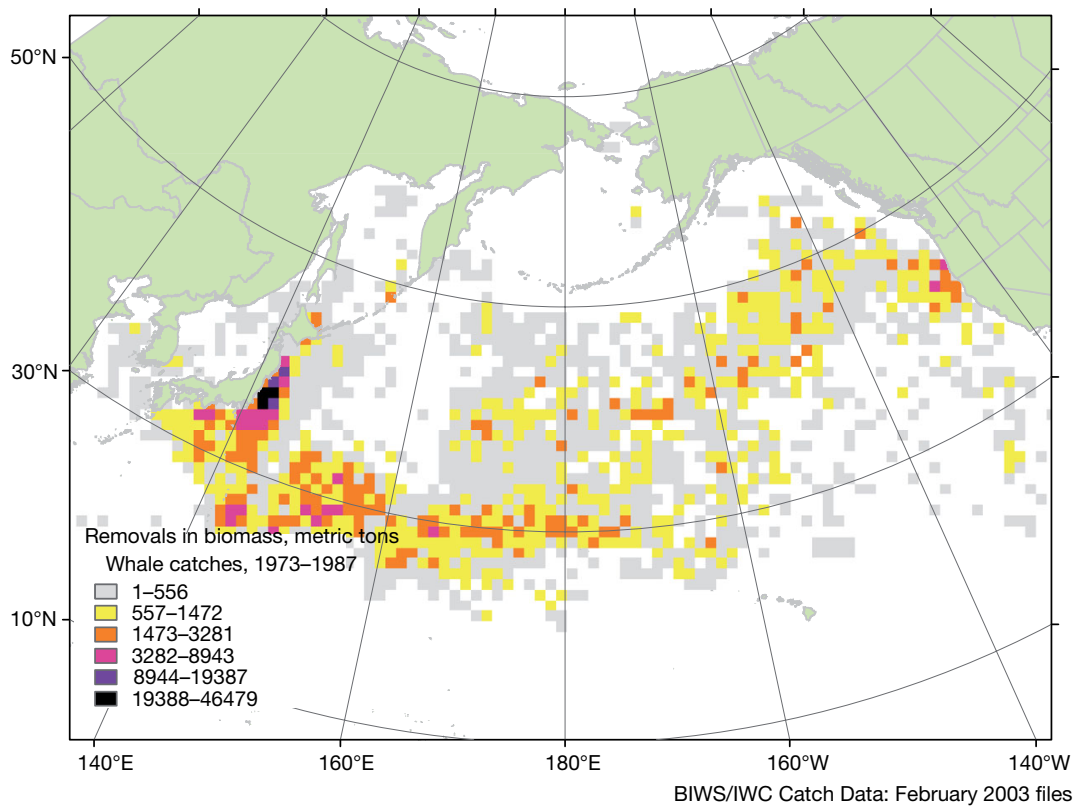

Fig. 6. Whale catches from 1973 to 1987, represented as biomass. Catches from 1973 and afterwards were nearly all south of the traditional whaling grounds and effort was concentrated north and south of $30^{\circ} \mathrm{N}$

\section{Observations of killer whales attacking large whales}

Encounters between killer whales and large baleen whales are not necessarily agonistic. Killer whales show a whole spectrum of responses to the nearby presence of baleen whales: ignoring them, following them, chasing them, actually biting them, and killing them (our observations, and see also Jefferson et al. 1991). It is only the latter 2 responses that are important in our context. Baleen whales likewise show a spectrum of responses to the proximity of killer whales; usually they ignore them or move away slowly, but Andrews (1914) reported that if gray whales Eschrichtius robustus 'are not paralyzed by fright they head for shore and slide in as close as possible to the beach.' Jefferson et al. (1991) extensively reviewed the interactions between killer whales and other species of marine mammals and noted '... at least occasionally, healthy non-calf baleen whales are fed upon'.

In an extensive (but not exhaustive) review of the literature going back as far as Bennett (1840) and extending to the year 1968, we could find only 11 accounts of killer whales attacking large or mid-sized whales in the North Pacific. These involved 2 fin whales, 1 bowhead whale Balaena mysticetus, 5 gray whales, 2 minke whales and 1 unidentified whale; 5 of these attacks resulted in the death of the whale, 3 failed, and in the other 3 instances the outcome could not be determined. These attacks are enumerated below.

Fin whale. Turner (1886) 'witnessed 2 of these creatures [killer whales] attacking a very large Finback Whale in the vicinity of Tigalda Island in the eastern Aleutians, sometime during the years 1874 and 1881. The latter was nearly exhausted by the persistent and impetuous lunges made upon it by its enemies'. The outcome of this encounter is not known.

As related by Pike \& MacAskie (1969), on 14 June 1960, near Marble Island, on the west side of the Queen Charlotte Islands, the crew of a Canadian Fisheries Vessel logged the sighting of 'killer whales attacking fin whale'.

Bowhead whale. According to Bailey \& Hendee (1926), Charles Brower of Barrow reported that killer whales were said to have once attacked and killed a bowhead whale off Point Barrow, Alaska.

Gray whale. Scammon (1874) saw 3 killer whales attack and kill a gray whale calf accompanied by its mother in a lagoon in Baja California. 


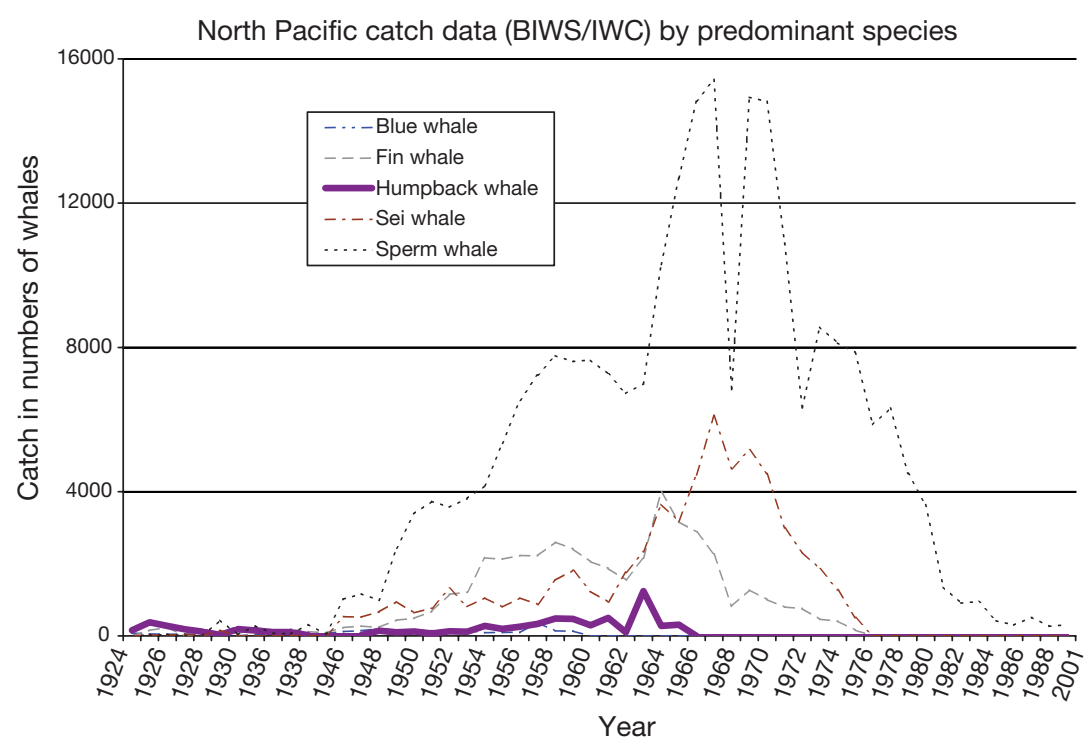

Fig. 7. Whale catch for each species by year, entire North Pacific combined. Note the peak in sperm whale Physeter macrocephalus catches in 1969, and the increase in sei whale catches after 1966

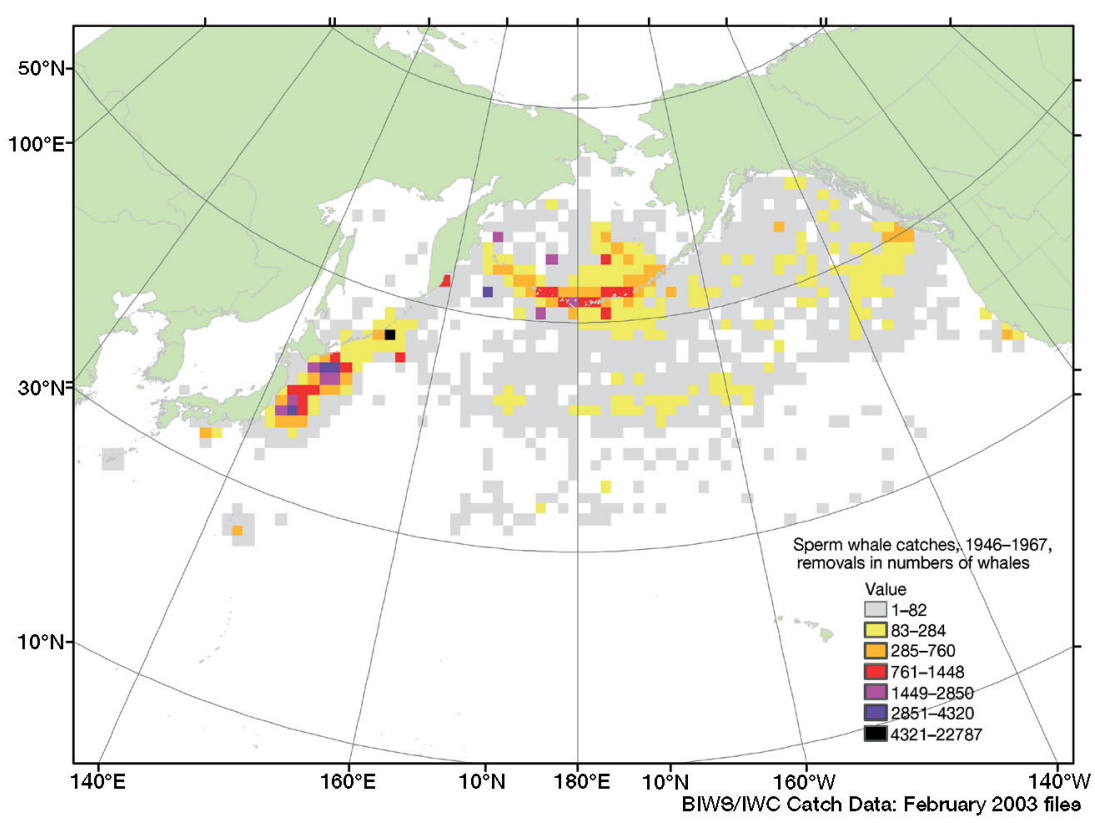

Fig. 8. Sperm whale catches from 1946 to 1967, in numbers of whales caught. These catches were concentrated off the Japanese mainland and off Kamchatka, the Bering Sea and the Aleutian Islands
Pike \& MacAskie (1969) reported killer whales attacking a pair of gray whales off the Queen Charlotte Islands, British Columbia.

Minke whale. There are at least 2 accounts of North Pacific killer whales attacking minke whales prior to 1968. Both attacks resulted in the death of the minke whale.

Hancock (1965) watched a pod of 7 killer whales attack and kill a minke whale on 26 May 1964 in Barkley Sound on the west coast of Vancouver Island, British Columbia. The pod consisted of 3 adult males, 2 adult females, and 2 calves. According to Hancock, 'very little happened above the surface to suggest what was going on below.' The next day, a minke whale carcass was found floating about 4.5 miles northeast of the site of the kill, and was towed to shore.

In the same area, on 20 July 1964, Hancock (1965) found the carcass of another minke whale that almost certainly had been killed by killer whales, because some of its skin and blubber had been stripped from its torso in the same way as on the whale found after the 26 May attack.

Unidentified whale. Tomilin (1967) gave the following second-hand account of an attack on an unidentified 'whale', perhaps a large baleen whale, near the Commander Islands in 1912: 'Two dead dolphins were thrown overboard from the warship 'Manchzhur.' The carcasses were soon approached by a pack of Killers. A whale happened to appear nearby. Having sensed the whale, the Killers left the dolphin carcasses and attacked him. A few hours later, the 'Manchzhur' found this whale dead on the surface of the sea.'
Scheffer (in Rice \& Wolman 1971) saw 6 killer whales unsuccessfully attack a gray whale in Monterey Bay, California on 9 March 1952.

Gilmore (1961) reported an unsuccessful attack by 6 killer whales on 2 gray whales at La Jolla, California. Morejohn (1968) observed an unsuccessful attack by 7 killer whales on 3 gray whales, including a female with a calf, at Moss Landing, California.

\section{DISCUSSION}

\section{Development and collapse of post-war whaling}

Springer et al.'s (2003) representation of the development and collapse of modern whaling in the North Pacific is not very accurate, either temporally and geographically. Based on the information in their 


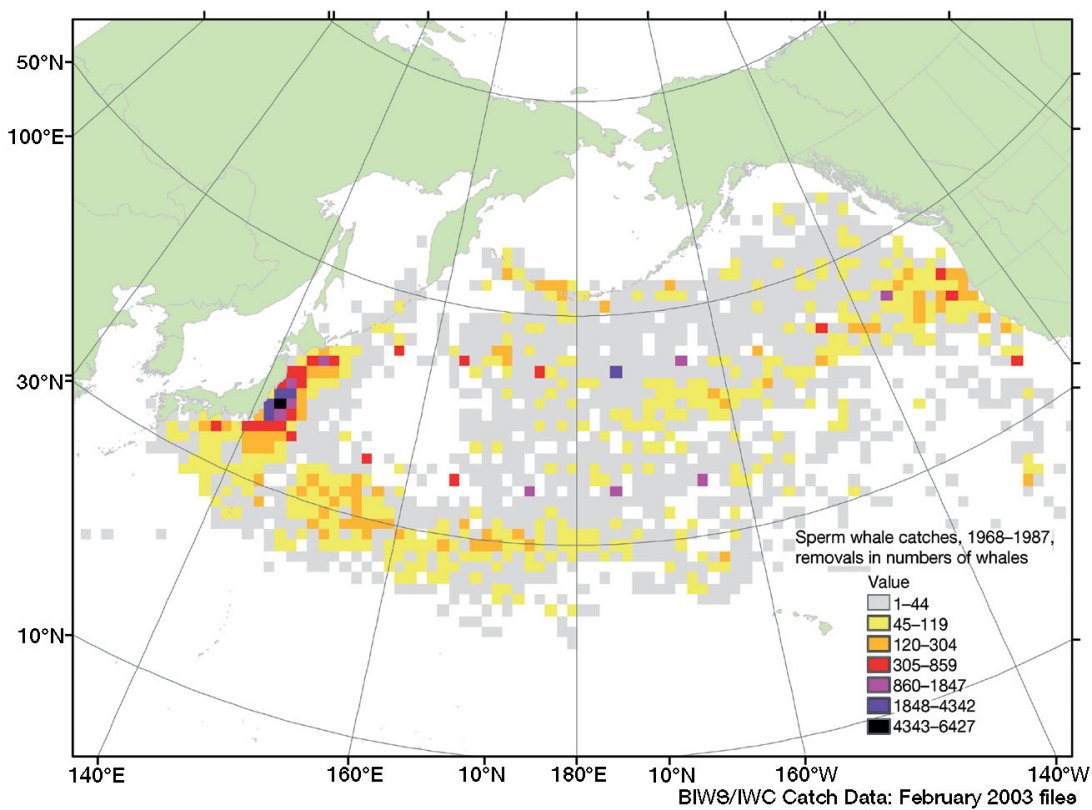

Fig. 9. Sperm whale catches from 1968 to 1987, in numbers of whales caught. By 1968, sperm whale catches were taken much farther south

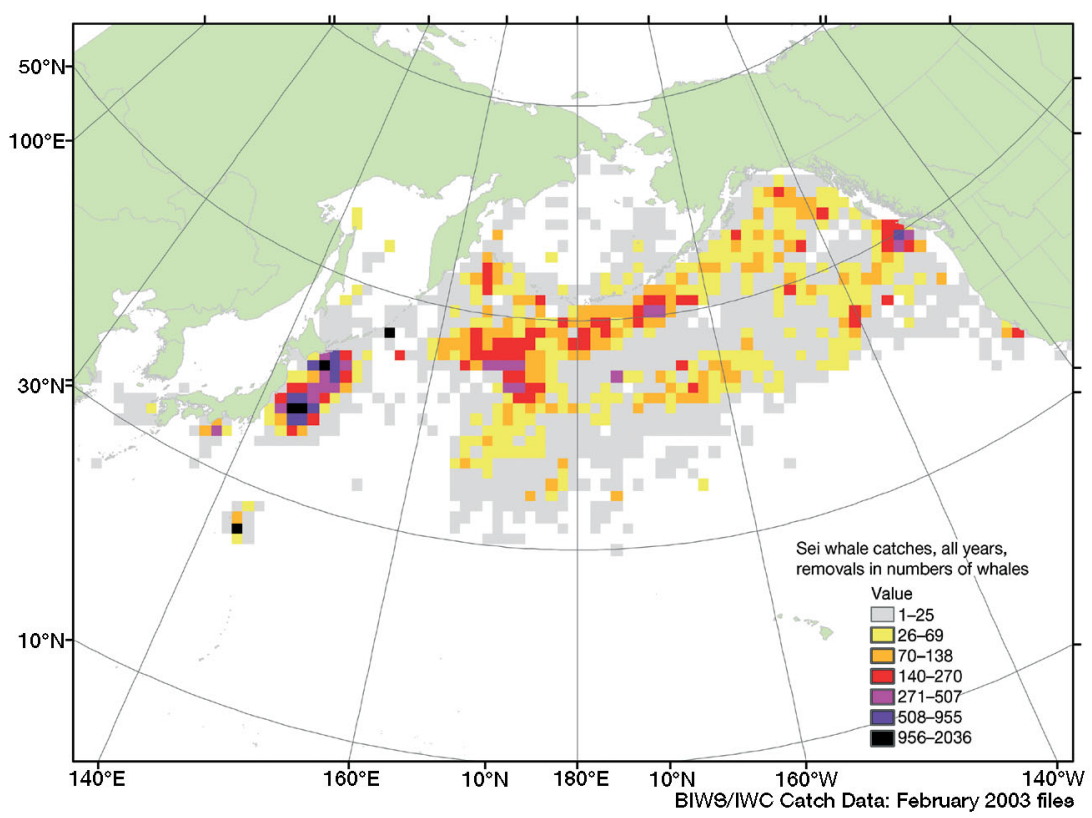

Fig. 10. Distribution of sei whale catches throughout the North Pacific, all years combined. Note that the primary zone of concentration of sei whales has always been much farther south, in the Subarctic Boundary area (ca. $42^{\circ} \mathrm{N}$ )

from 2 factory ships with 9 catcher boats in 1953 to 7 factory ships with 67 catcher boats in 1963 (Anonymous 1965). Whaling spread throughout the Kamchatka, Bering Sea/Aleutian Islands and Gulf of Alaska whaling grounds because whale abundance was seasonally high in broad areas throughout the North Pacific, and whalers were able to maximize their catch by moving where the whale densities were highest.

Based on our Figs. 2 to 5, the bulk of the whaling that would have affected killer whales was conducted throughout the traditional whaling grounds off Kamchatka, in the Bering Sea and around the Aleutian Islands, and in the Gulf of Alaska, all of which are north of $50^{\circ} \mathrm{N}$. Although mammal-eating killer whales have been documented to travel long distances (Goley \& Straley 1994), if killer whales were highly dependent on great whales as prey, we would assume that large whale declines throughout the entire northern area would have an impact on killer whales starting in 1968 (i.e. if the theory of Springer et al. [2003] is correct).

We agree with Springer et al. (2003) that the BIWS/IWC catch dataset under-represents true biomass removals because it does not include recently revealed data on illegal whaling. This illegal whaling was conducted from 1961 to 1972 , simultaneously with and on the same grounds as the legal whaling, so the temporal and geographic trends in the whaling data should be accurate, with only some of the biomass totals assumed to be too low. As reported in Doroshenko (2000a), the Soviets began illegal whaling for humpback whales in the North Pacific in 1962, and misreported catches on a large scale through 1967. The total catch of humpback whales (including unreported catches) peaked in 1963 and was at

Fig. 1A,B, Springer et al. (2003) stated that whalers moved eastward as whale stocks close to Japan and the USSR were depleted. Based on our revised figures (Figs. 2 to 5), catches close to homeports remained high (i.e. not depleted) as whaling expanded to other areas throughout the North Pacific. The geographic spread was due to expansion of the whaling industry, not to localized depletions. Pelagic whaling effort increased very low levels by 1966. Illegal whaling and unreported catches of blue, gray, bowhead and right whales (Eubalaena glacialis; for taxonomic status, see Baker et al. 2003) began in 1963, peaked in 1964, and were at much lower levels by 1966 (Doroshenko 2000b).

As noted above, it is likely that sperm whaling south of $50^{\circ} \mathrm{N}$ caused the second peak in Springer et al.'s Fig. 2, which leaves a large time gap between the ces- 


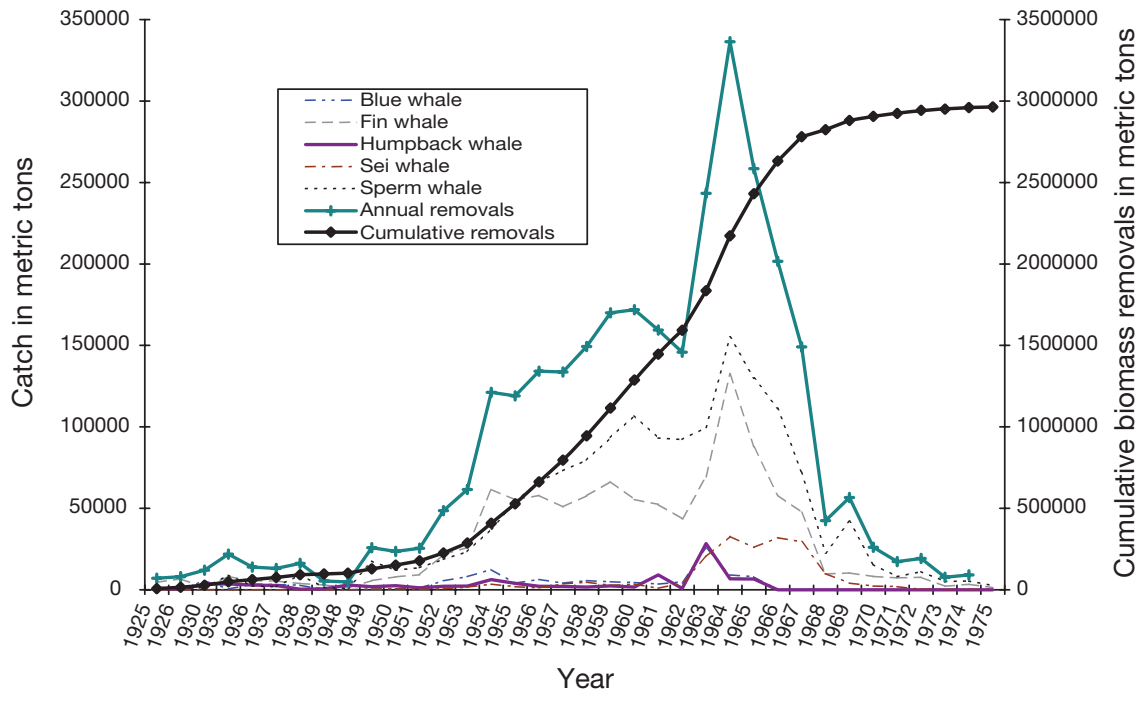

Fig. 11. Biomass removals and cumulative biomass removed for catches $50^{\circ} \mathrm{N}$ and above for the entire range of years in the BIWS/IWC catch database. Note that that the last big year of whale biomass removals from $50^{\circ} \mathrm{N}$ and above was 1967 , and subsequent removals from 1968 onwards were negligible sation of whaling in the Bering Sea/Aleutian Islands and Gulf of Alaska regions and the declines represented in their Fig. 2.

The catch maps in Springer et al. (2003) mask the nature of the slow development and precipitous decline of whaling in the North Pacific. The extraordinary biomass removals in the early 1960s, even without including the newly discovered records of illegal whaling, would lead one to assume that any whalingrelated prey shifting should have begun by 1968, not by the mid-1970s as their Fig. 2 indicates.

The last big year of whaling in the northern areas was 1967 . Whalers left the traditional whaling grounds and switched to the rich grounds along the Subarctic Boundary after 1972, and whaling in the northern whaling grounds really ended well before 1972 .

If killer whales had been dependent on great whale stocks as a major source of prey, the effects should have been apparent from 1964, the year of the highest biomass removals, and by 1968, killer whales would have been exerting great pressure on nearby pinniped populations.

\section{Large whale biomass removals}

Springer et al.'s (2003) Fig. 2 is described as representing 'Great Whale Biomass', but the caption states that it represents 'whale landings in biomass within $370 \mathrm{~km}$ of the Aleutian archipelago and coast of the western Gulf of Alaska'. At first glance, without reading the figure caption, it appears that whale biomass started at low levels, spiked twice, and plummeted. The figure is on the same plot as curves meant to represent sequential declines in abundance of various pinniped species. What is worrisome is that our analyses of catch curves and biomass removals, using the same dataset, cannot replicate the curve presented in Springer et al.'s (2003) Fig. 2. Also, it is not clear what method these authors used to calculate the 'biomass' presented in Fig. 2.

Springer et al. (2003) stated that 'combined current biomass is estimated to be only $\sim 14 \%$ of pre-exploitation levels', based on 'Pfister (in press)'. However, the Pfister (2004) estimate as published was 18\% (not $14 \%$ ), and Pfister noted that the estimate was very sen-

Table 1. Summary of finds of whale remains in killer whale stomachs from the North Pacific

\begin{tabular}{|c|c|c|c|c|c|c|c|c|}
\hline Locality collected & $\begin{array}{l}\text { Years } \\
\text { collected }\end{array}$ & $\begin{array}{l}\text { Number of } \\
\text { stomachs } \\
\text { examined }\end{array}$ & $\begin{array}{l}\text { Number } \\
\text { with } \\
\text { food } \\
\text { items }\end{array}$ & $\begin{array}{l}\text { Number } \\
\text { with } \\
\text { mammal } \\
\text { remains }\end{array}$ & $\begin{array}{l}\text { Number } \\
\text { with } \\
\text { whale } \\
\text { remains }\end{array}$ & $\begin{array}{c}\text { Percent of } \\
\text { mammal } \\
\text { eaters with } \\
\text { whale } \\
\text { remains }\end{array}$ & $\begin{array}{l}\text { Speci } \\
\text { nur } \\
\text { of } w \\
\text { Sei }\end{array}$ & $\begin{array}{l}\text { ies and } \\
\text { mber } \\
\text { hales } \\
\text { Minke }\end{array}$ \\
\hline Olyutorskiy and Anadyrskiy gulfs ${ }^{\mathrm{a}}$ & 1936 & 2 & 2 & 2 & 0 & 0 & & \\
\hline Coastal waters around Japan ${ }^{\mathrm{b}}$ & $1948-1957$ & 409 & 380 & 102 & 2 & 1.96 & 2 & \\
\hline Kuril Islands ${ }^{\mathrm{c}}$ & 1951-1955 & 21 & 10 & 0 & 0 & 0 & & \\
\hline $\begin{array}{l}\text { Kodiak Island, AK, } \\
\text { to San Miguel Island, } \mathrm{CA}^{\mathrm{d}}\end{array}$ & 1960-1967 & 10 & 8 & 6 & 1 & 16.7 & & 1 \\
\hline Total during whaling years & Prior to 1968 & 442 & 400 & 110 & 3 & 2.72 & & \\
\hline
\end{tabular}


sitive to the inclusion of sperm whales. If sperm whale biomass were excluded because the peak of the sperm whale catch occurred south and west of $50^{\circ} \mathrm{N}$ (Figs. 1 \& 7; see also DeMaster et al. in press), the estimated current biomass of large whales is estimated to be $46 \%$ of pre-exploitation biomass.

\section{Killer whale prey choices}

Based on analysis of stomach contents, the only evidence that North Pacific killer whales preyed upon large or mid-sized whales during the industrial whaling era were the remains of 2 sei whales in the stomachs of 2 killer whales taken in Japanese waters (Nishiwaki \& Handa 1958) and the minke whale remains in a killer whale taken on 22 March 1965 off Point Conception, California in the eastern North Pacific (Rice 1968).

The earliest serious student of marine mammals in the North Pacific was Charles M. Scammon; during his years as captain of whaling vessels (1852 to 1874), he reported seeing killer whales attacking baleen whales only once (Scammon 1874). He concluded that 'the Orca, however, does not always live on such gigantic food, and we incline to the belief that it is but rarely that these carnivora of the sea attack the larger Cetaceans, but chiefly prey with great rapacity upon their young'.

In the North Atlantic, the Norwegian cetologist Agge Jonsgård, in discussing the prey species of killer whales, asserted that 'with regard to cetaceans it is obviously true that it is mainly small-sized porpoises that have been the prey.' He reported, 'during the many years of Norwegian whaling in the Norwegian Sea and adjacent Arctic waters for minke whales and other whalebone whales, we have had no reports from the whalers about these animals being attacked by killer whales' (Jonsgård 1968b). He concluded that 'there is no proof that baleen whales and other large cetaceans in good health and under normal conditions are attacked by killer whales' (Jonsgård 1968a).

\section{Recent observations of killer whales attacking large whales}

Recent observations confirm that minke whales and gray whales (especially gray whale calves) may be at least an occasional target for North Pacific killer whales.

Minke whale

Minke whales have been seen being attacked and killed by killer whales on a number of occasions in the North Pacific after 1968:
In the Gulf of Alaska just south of Yakutat Bay, at $58^{\circ} 22^{\prime} \mathrm{N}, 138^{\circ} 21^{\prime} \mathrm{W}$, on 29 April 1976, Marsha Caunt Schad of the Marine Mammal Division, National Marine Fisheries Service, saw a small pod of killer whales attacking and killing a minke whale (Fiscus et al. 1976). This is apparently the same incident that was said to have been observed 'off Yakutat' in 'late winter' 1977, as related by Hall (1986).

Off the west side of Amaknak Island $\left(53^{\circ} 54^{\prime} \mathrm{N}\right.$, $166^{\circ} 53^{\prime} \mathrm{W}$ ) in the eastern Aleutian Islands, on 5 August 1975, Robert R. Nelson saw a pod of 7 killer whales chasing a minke whale (Lowry et al. 1987) which was later found dead. In Prince William Sound, Alaska, on an unspecified day in 1982, Mehlberg (1986) observed and photographed a pod of killer whales as they killed a minke whale.

In Johnstone Strait, British Columbia, Dorsey et al. (1990) photographed a minke whale bearing a series of parallel scars on its left flank just anterior to the dorsal fin. The scars had almost certainly been inflicted by the teeth of a killer whale.

In Icy Strait in southeastern Alaska in 1996, a pod of 13 killer whales was seen to kill a minke whale (Matkin et al. 1999).

In Ganges Harbour on Saltspring Island, British Columbia, on 15 October 2002, Lance Barrett-Lennard and about 200 spectators witnessed the killing of a minke whale (Anonymous 2002).

In Alaska and British Columbia, 8 attacks of killer whales on minke whales, 5 of which were successful, were reported by Ford et al. (1998) and Matkin \& Saulitis (1994), but they provided no further particulars.

There has never been a commercial fishery for minke whales in the North Pacific (except locally around Japan), so there is no reason to believe that their population has changed significantly during the latter half of the 20th century, nor that their contribution to the diet of killer whales has changed. The importance of minke whales as prey of killer whales differs greatly in other parts of the world. In the Atlantic sector of the Southern Ocean, Budylenko (1981) documented that in the cold Antarctic waters the closely related Antarctic minke whales Balaenoptera bonaerensis are the dominant prey of killer whales. However, in Norwegian waters, both killer whales and minke whales are commonly seen. In his monograph on the mammals of Norway, Collett (1911-12), who had a special interest in cetaceans, did not include the minke whale among the prey of the killer whale; the only mammals he listed as prey were harbor seal, gray seal, and harbor porpoise. Jonsgård (1968b) reported that whalers operating in the Norwegian Sea and adjacent Arctic Ocean never reported minke whales being attacked by killer whales. 


\section{Gray whale}

Rice \& Wolman (1971) found healed parallel scars that were obviously the tooth marks of killer whales on $57(18 \%)$ of the 316 gray whales that they examined at the whaling stations on Point San Pablo, California from 1959 to 1969. There are also a number of observations of killer whales successfully attacking adult gray whales, but most attacks on this species are directed at young calves. Most notably, at certain places and times of the year, killer whales regularly prey on gray whale calves.

Each year the gray whales with their young calves migrate north along the coast from Baja California to the Bering Sea, passing through the areas inhabited by known mammal-eating killer whales. Around Monterey Bay, California, killer whales congregate every year in the late spring when female gray whales with their young calves are migrating north close to the shore. Nancy Black and Richard Ternullo have studied these killer whales for 15 yr (Black 2001, 2003, Ternullo $\&$ Black 2002). During this period they have observed 84 predation events by the killer whales, of which 25 (30\%) involved the killing of gray whale calves and $29(35 \%)$ involved the killing of California sea lions Zalophus californianus. The remaining prey included lesser numbers of porpoises, dolphins, elephant seals, and seabirds.

In the area around False Pass in the Aleutian Islands, ongoing studies indicate that killer whales regularly attack gray whales-mainly calves-during their spring migration through this area (C Matkin \& L. Barrett-Lennard, North Gulf Oceanic Society and Vancouver Aquarium, unpubl. data). In the coastal waters of the Chukotski Peninsula, during the ice-free seasons of the years 1990 to 2000, Inuit hunters reported all of their observations of killer whale predation on marine mammals (Melnikov \& Zagrebin 2005). Of 92 attacks on marine mammals, 61 (66\%) were on gray whales; of these 23 resulted in successful kills, 6 were unsuccessful, and the outcome was unknown in the other 32 . The remaining 31 attacks were made on walruses, Steller sea lions, belugas, bowhead whales (2), and fish (1). In the same area, from 1993 to 2000, 69 stranded carcasses of gray whales were found; 31 of these appeared to have been killed by killer whales. Ten of 14 were less than $8 \mathrm{~m}$ long, and judged to be less than $1 \mathrm{yr}$ old; 2 others were less than $9 \mathrm{~m}$, and were judged to be less than 2 yr old; the largest was a $12 \mathrm{~m}$ long adult.

Gray whales were not a target of post-war industrial whaling. At the end of the industrial whaling period, the gray whale population was at a fairly substantial level and continued to increase steadily. The estimated number of gray whale adults ranged between 10000 and 12000 in the late 1960s (Reilly et al. 1983) and gray whales have continued to increase to levels of 18000 to 25000 in recent years (Rugh et al. 2005).

Baird (2002) discussed prey choice in mammaleating killer whales, taking into account prey profitability and risk of injury, and noted that predation on large baleen whales should be rare, on theoretical grounds. There are no data to support the idea that the large balaenopterids (blue, fin, and humpback whales) or sperm whales were ever preyed upon by North Pacific killer whales, except under rare and exceptional circumstances.

Springer et al. (2003) cited Budylenko (1981), using data from the southern hemisphere, as corroboration that killer whale attacks on large whales are fairly common, stated that, based on Budylenko's studies, $>60 \%$ of sperm whales were found to have killer whale scars. However, upon closer reading, Budylenko (1981) indicates that although Antarctic minke whales were the dominant prey species, no other great whale remains were found in any of the killer whale stomachs sampled. Furthermore, Budylenko (1981) states 'as is evident from direct observations, killer whales can attack large whales ... however many of these larger whales manage to escape.' Based on stomach content data collected by Yukhov et al. (1976) in the southern hemisphere, killer whales sampled in the Indian Ocean sector of the southern hemisphere $\left(53-55^{\circ} \mathrm{S}\right)$ appear to feed exclusively on Antarctic minke whales and he concluded that minke whales were the 'main item' in the diet of minke whales near the Antarctic ice edge. Shevchenko (1976) noted that in cold waters south of $50^{\circ} \mathrm{S}$, minke whale remains were found in over $84 \%$ of killer whale stomachs and stated 'not one single stomach was found to contain the remains of sperm whales or large baleen whales'.

Many researchers have noted that adult sperm whales are almost never attacked by killer whales (Beale 1839, Berzin 1972, Rice 1989) - notwithstanding one exceptional lethal attack witnessed off California (Pitman et al. 2001). Their large size and their ability to make deep and prolonged dives would make them a difficult prey item. Killer whales have been seen attempting to capture newborn calves in breeding schools of southern hemisphere sperm whales (Berzin 1972, Yukhov et al. 1976, Best et al. 1984), and 1 dead sperm whale calf was found with wounds that appeared to have been inflicted by killer whales (Best et al. 1984). Sperm whale remains have been recovered from the stomachs of killer whales in the subtropical southern hemisphere (Yukhov et al. 1976). Shevchenko (1976) and Budylenko (1981) claim to have found scars inflicted by the teeth of killer whales on the bodies of sperm whales, but it may be difficult to distinguish between such scars and those which are commonly inflicted by intraspecific aggression. Rice 
found scars attributable to killer whales on only 1 of 637 sperm whales landed at the whaling stations on Point San Pablo, California, between 1959 and 1970.

\section{CONCLUSIONS}

The catch maps in Springer et al. (2003) masked the nature of the slow development and precipitous decline of whaling in the North Pacific. The extraordinary biomass removals in the early 1960s (even without the newly exposed surreptitious illegal whaling operations), would lead one to conclude that any whaling-related prey shifting should have begun by 1968, not by the mid-1970s as their Fig. 2 indicates. The last big year of whaling in the northern areas was 1967. After that, the whalers left their traditional whaling grounds and moved south to the rich grounds along the Subarctic Boundary (ca. $42^{\circ} \mathrm{N}$ ). If killer whales had been dependent on great whales (the large rorquals and the sperm whale) stocks as a major source of prey, the effects should have been apparent starting from 1964, the year of the highest biomass removals, and by 1968, killer whales would have been exerting great pressure on nearby pinniped populations. DeMaster et al. (in press) reanalyzed the pinniped data in Springer et al.'s (2003) Fig. 2 and found concurrent, not sequential, declines in abundance for fur seals and harbor seals, followed by declines in Steller sea lions, starting after the late 1970s.

Our review of the historical record confirmed that great whales have never been more than a rare item in the diets of killer whales, either before or after the depletion of the great whale populations in the North Pacific during the whaling era. Killer whales rarely attacked healthy, adult individual great whales, and such attacks were usually unsuccessful.

In the North Pacific, attacks on minke whales were occasionally witnessed and such attacks usually resulted in a kill. Minke whales were never a target of industrial whaling in the northern North Pacific or Bering Sea, and would have been available as prey for killer whales before, during, and after the industrial whaling period.

Adult gray whales are occasionally attacked by killer whales, but the frequency of tooth scars indicate that many targeted animals succeed in escaping the killer whales. On the other hand, recent studies have documented that at certain times and places killer whales regularly prey upon gray whale calves during their northward migration. The gray whale population was growing steadily through the 20th century, so gray whales would have become increasingly available as prey for killer whales even as the other great whale stocks were being depleted.
If killer whales had been dependent on great whale stocks as a major source of prey, the effects should have been apparent starting from 1964, the year of the highest whaling biomass removals. By 1968, killer whales would have been exerting great pressure on nearby pinniped populations. There is no evidence of declines during this period in any of the trend data for the pinniped populations in the region.

Acknowledgements. M. Cameron, National Marine Mammal Laboratory (NMML), provided timely technical assistance with ArcMap support, and A. Zerbini, NMML, provided insightful scientific suggestions as the paper was in development. R. Angliss, R. Baird, N. Friday and R. Reeves, K. Stafford, G. Duker, J. Lee and an anonymous reviewer provided thoughtful review comments that greatly improved the paper. C. Matkin and L. Barrett-Lennard provided access to unpublished data.

\section{LITERATURE CITED}

Andrews RC (1914) Monographs of the Pacific Cetacea. I. The California gray whale (Rhachianectes glaucus Cope). Mem Am Mus Nat Hist (New Ser) 1:227-287

Anonymous (ed) (1965) International Whaling Statistics, Vol LV. Comm Whaling Stat, Oslo

Anonymous (2002) Transient orcas kill minke whale in Ganges Harbour. Vancouver Aquarium Aquanews. October 16, 2002

Bailey AM, Hendee RW (1926) Notes on the mammals of northwestern Alaska. J Mammal 7:9-28

Baird RW (2002) Killer whales of the world: natural history and conservation. Voyager Press, Stillwater, MN

Baker R, Bradley L, Bradley R, Dragoo J and 6 others (2003) Revised checklist of North American mammals north of Mexico, 2003. Occas Pap Mus Texas Tech Univ 229:1-23

Balcomb K (1989) Baird's beaked whale Berardius bairdii Stejneger, 1883: Arnoux's beaked whale Berardius arnuxii Duvernoy. In: Ridgway SH, Harrison R (eds) Handbook of marine mammals, 4, river dolphins and the larger toothed whales, Vol 4. Academic Press, London, p 261-288

Beale $\mathrm{T}$ (1839) The natural history of the sperm whale. John Van Voorst, London

Bennett FD (1840) Narrative of a whaling voyage around the globe from the year 1833 to 1836. Richard Bentley, London

Berzin AA (1972) The sperm whale. Israel Program for Scientific Translations, Jerusalem (translation from Russian)

Best PB, Canham PAS, MacLeod N (1984) Patterns of reproduction in sperm whales (Physeter macrocephalus). Rep Int Whaling Comm Spec Iss:51-79

Bigg MA, Ellis GM, Ford JKB, Balcomb KC III (1987) Killer whales: A study of their identification, genealogy, and natural history in British Columbia and Washington State. Phantom Press, Nanaimo, BC

Black N (2001) Gray whales off Monterey. Monterey Bay Whale Watch, Pacific Grove, CA

Black N (2003) The gray whale migration off Monterey. Monterey Bay Whale Watch, Pacific Grove, CA

Budylenko GA (1981) Distribution and some aspects of the biology of killer whales in the South Atlantic. Rep Int Whaling Comm 31:523-525

Collett R (1911-12) Norges pattedyr. H. Aschenoug, Kristiania DeMaster D, Trites A, Clapham P, Mizroch S, Wade P, Small R, Ver Hoef JM (in press) The cascading whale predation hypothesis: Testing with existing data. Proc Oceanogr

Doroshenko N (2000a) Soviet catches of humpback whales 
(Megaptera novaeangliae) in the North Pacific. In: Yablokov AV, Zemsky VA (eds) Soviet whaling data (1949-1979). Center for Russian Environmental Policy, Marine Mammal Council, Moscow, p 48-95

Doroshenko N (2000b) Soviet whaling for blue, gray, bowhead and right whales in the North Pacific Ocean, 1961-1979. In: Yablokov A, Zemsky V (eds) Soviet whaling data (1949-1979). Center for Russian Environmental Policy, Marine Mammal Council, Moscow, p 96-103

Dorsey EM, Stern SJ, Hoelzel AR, Jacobsen J (1990) Minke whales (Balaenoptera acutorostrata) from the west coast of North America: individual recognition and small scale site fidelity. Rep Int Whal Comm Spec Iss 12:357-368

Fiscus $\mathrm{CH}$, Braham HW, Mercer RW, Everitt RD and 5 others (1976) Seasonal distribution and relative abundance of marine mammals in the Gulf of Alaska. Northwest and Alaska Fisheries Center (NWAFC), Marine Mammal Division, Seattle, WA (errata, figure, i-vi, 1-237)

Ford J, Ellis G, Barrett-Lennard L, Morton A, Palm R, Balcomb K (1998) Dietary specialization in 2 sympatric populations of killer whales (Orcinus orca) in coastal British Columbia and adjacent waters. Can J Zool-Revue Canadienne de Zoologie 76:1456-1471

Gilmore R (1961) The story of the gray whale. Privately published, San Diego, CA

Goley PD, Straley JM (1994) Attack on gray whales (Eschrichtius robustus) in Monterey Bay, California, by killer whales (Orcinus orca) previously identified in Glacier Bay, Alaska. Can J Zool 72:1528-1530

Hall JD (1986) Notes on the distribution and feeding behavior of killer whales in Prince William Sound, Alaska. In: Kirkevold BC, Lockard JS (eds) Behavioral biology of killer whales. Zoo Biology Monographs, Vol 1. Alan R. Liss, New York, p 69-84

Hancock D (1965) Killer whales kill and eat a minke whale. J Mammal 46:341-342

Heise K, Barrett-Lennard LG, Saulitis E, Matkin C, Bain D (2003) Examining the evidence for killer whale predation on Steller sea lions in British Columbia and Alaska. Aquat Mamm 29: 325-334

Ivanova EI (1961) O tikhookeanskoy kosatke (Orcinus orca, L.) Tr Inst Morfol Zhivotn Akad Nauk SSSR 34:205-215

Jefferson TA, Stacey PJ, Baird RW (1991) A review of killer whale interactions with other marine mammals: predation to $\mathrm{co}-$ existence. Mammal Rev 21:151-180

Jenks G (1963) Generalization in statistical mapping. Ann Assoc Am Geogr 53:15-26

Jonsgård Å (1968a) Another note on the attacking behavior of killer whale (Orcinus orca) Norsk Hvalfangst-Tidende 57 6:175-176

Jonsgård Å (1968b) A note on the attacking behavior of the killer whale (Orcinus orca) Norsk Hvalfangst-Tidende 57 4:84-85

Lockyer C (1976) Body weights of some species of large whales. J Conseil Int Explor Mer 36:259-273

Lowry LL, Nelson RR, Frost KJ (1987) Observations of killer whales, Orcinus orca, in western Alaska: sightings, strandings, and predation on other marine mammals. Can Field-Nat 101:6-12

Matkin CO, Saulitis E (1994) Killer whale (Orcinus orca) biology and management in Alaska. Contract No. T75135023, Marine Mammal Commission, Washington, DC

Matkin C, Ellis G, Saulitis E, Barrett-Lennard L, Matkin D (1999) Killer whales of southern Alaska. North Gulf Oceanic Society, Homer, AK

Mehlberg J (1986) Wolves of the sea. Men watch as orcas kill minke whale. Alaska Magazine 52:46-48, available at www.alaskamagazine.com

Melnikov VV, Zagrebin IA (2005) Killer whale predation in coastal waters of the Chukotka Peninsula. Mar Mamm Sci 21: $550-556$

Editorial responsibility: Howard I. Browman (Associate Editor-in-Chief), Storebø, Norway
Mizroch SA (1983) Reproductive rates in Southern Hemisphere baleen whales. MSc thesis, University of Washington

Morejohn G (1968) A killer whale-gray whale encounter. J Mammal 49:327-328

Nishiwaki M, Handa C (1958) Killer whales caught in the coastal waters off Japan for recent 10 years. Sci Rep Whales Res Inst 13:85-96

Perez MA (1990) Review of marine mammal population and prey information for Bering Sea ecosystem studies. NOAA Tech Memo NMFS F/NWC-186, US Dept Commerce, NOAA, Natl Mar Fish Serv 1-81

Pfister B (2004) Computations of historic and current biomass estimates of marine mammals in the Bering Sea. AFSC Processed Report 2004-05, Alaska Fisheries Science Center, Seattle, WA

Pike G, MacAskie I (1969) Marine mammals of British Columbia. Bull Fish Res Board Can 171:154

Pitman R, Ballance L, Mesnick S, Chivers S (2001) Killer whale predation on sperm whales: Observations and implications. Mar Mamm Sci 17:494-507

Reilly S, Rice D, Wolman A (1983) Population assessment of the gray whale, Eschrichtius robustus, from California shore censuses, 1967-1980. Fish Bull US 81:267-281

Rice DW (1968) Stomach contents and feeding behavior of killer whales in the eastern North Pacific. Norsk Hvalfangst-Tidende 2:35-38

Rice DW (1989) Sperm whale Physeter macrocephalus Linneaus, 1758. In: Ridgway SH, Harrison RJ (eds) Handbook of marine mammals, Vol 4. Academic Press, London, p 177-233

Rice DW, Wolman AA (1971) The life history and ecology of the gray whale (Eschrichtius robustus). Am Soc Mammal Spec Publ No. 3

Rugh D, Hobbs R, Lerczak J, Breiwick J (2005) Estimates of abundance of the eastern North Pacific stock of gray whales 1997-2002. J Cetacean Res Manag 7:1-12

Scammon C (1874) The marine mammals of the north-western coast of North America, described and illustrated: together with an account of the American whale-fishery. John $\mathrm{H}$. Carmany, San Francisco, CA

Shevchenko VI (1976) The nature of interrelationships between killer whales and other cetaceans. Department of the Environment, Fisheries and Marine Service, Ste. Anne de Bellevue, Quebec (translated from Russian)

Springer A, Estes J, van Vliet G, Williams T, Doak D, Danner E, Forney K, Pfister B (2003) Sequential megafaunal collapse in the North Pacific Ocean: An ongoing legacy of industrial whaling? Proc Natl Acad Sci USA 100:12223-12228

Ternullo R, Black N (2002) Predation behavior of transient killer whales in Monterey Bay, CA. Monterey Bay Whale Watch Res Rep

Tomilin AG (1967) Mammals of the U.S.S.R. and adjacent countries, Vol IX. Cetacea. Israel Program for Scientific Translations, Jerusalem (Translated from Russian)

Trites A, Pauly D (1998) Estimating mean body masses of marine mammals from maximum body lengths. Can J Zool 76: 886-896

Turner LM (1886) Contributions to the natural history of Alaska. Results of investigations made chiefly in the Yukon district and the Aleutian Islands: conducted under the auspices of the Signal Service, United States Army, extending from May, 1784, to August, 1861. Government Printing Office Washington (extract)

Yukhov VL, Vinogradova EK, Medvedev LP (1976) The diet of killer whales (Orcinus orca L.) in the Antarctic and adjacent waters. Department of the Environment, Fisheries and Marine Service, Ste. Anne de Bellevue, Quebec (translated from Russian)

Zenkovich BA (1938) O kosatke ili kite-ubiitse. Priroda 1938: 109-112

Submitted: May 6, 2005; Accepted: September 3, 2005

Proofs received from author(s): February 18, 2006 